\title{
CGA Gene
}

National Cancer Institute

\section{Source}

National Cancer Institute. CGA Gene. NCI Thesaurus. Code C129840.

This gene plays a role in protein hormone signaling. 